\title{
Factors that Impact the Financial Performance of Broiler Production in Southern States of Paraná, Brazil
}

-Author(s)
Mendes AS'
Gudoski DC'
Cargnelutti AF"
Silva EJ'
Carvalho EH'
Morello GM"
| Technologic Federal University of Paraná
(UTFPR) - Campus Dois Vizinhos/PR.
" Federal University of Santa Maria/UFSM.
"I" Purdue University, West Lafayette, IN, U.S.

-Mail Adress

Corresponding author e-mail address Angélica Signor Mendes

Technologic Federal University of Paraná (UTFPR) - Campus Dois Vizinhos/PR.

Estrada para Boa Esperança, km 04, Cx.P 157, 85660-000

E-mail address: angelica@utfpr.edu.br

\section{nKeywords}

Costs, economic efficiency, poultry production, social-economic status.

Submitted: June/2012

Approved: November/2013

\section{ABSTRACT}

This study aimed at identifying the factors that affect the financial performance of broiler chicken production in Southwest of Paraná state in Brazil, as well as to study the relationship of these factors with the social-economic situation of poultry farmers. Data were obtained from a questionnaire applied to broiler chicken farmers between February and March, 2011. The questionnaire included 39 questions relative to farmer's age, family size, land possession, capital invested in broiler farming, gross income per flock, training and broiler farming experience, production size, credit needs, technical service, labor, production problems, and bird weight at slaughter. Data were submitted to descriptive statistical analysis. The relationship between production data and financial performance was determined using Pearson correlation coefficient, at 95\% confidence level. Approximately $64.84 \%$ of the interviewed broiler farmers in Paraná state presented medium to low financial performance. Factors such as education level, facility size, labor, gross income per flock, and average bird weight at slaughter had a positive impact on financial performance. The production problems that most affected the broiler production were environmental challenges, poor feed conversion, as well as management problems and low-quality chicks.

\section{INTRODUCTION}

During the last few years, poultry production has greatly developed. In 2008, chicken meat accounted for $2.94 \%$ of total Brazilian exports volume, and it is the fourth largest product in exports revenues. The state of Paraná is the largest Brazilian chicken meat producer and exporter (UBABEF, 2011).

Productivity developments and production-chain coordination progress increased the competitiveness of the poultry industry in Brazil, which is based in a vertical production system that integrates small farmers and large poultry companies. This allows poultry farmers to reduce capital investments in farming and also reduces their risks (Figueiredo et al., 2006).

Determining the causes that may affect poultry production profitability is essential for the farmers' economic progress, and may contribute for the development of public and private policies. One of the most convenient measures of success is profitability, because it is observable and it is not subject to interpretation (Duffy \& Nanhou, 2003).

Farm profitability depends on internal and external factors. The main internal factors are economy of size, farmer's age, his/her dedication to the farm, efficiency in the use of machinery, land productivity, use of managerial technology (Duffy \& Nanhou, 2003). 
Mendes AS, Gudoski DC, Cargnelutti AF, Silva EJ, Carvalho EH, Morello GM
Factors that Impact the Financial Performance of Broiler Production in Southern States of Paraná, Brazil
The identification of these factors may support the establishment of strategies to improve broiler farming profitability. Literature information on the factors that affect broiler farming in Southwestern state of Paraná, Brazil, are still scarce.

Therefore, the objective of the present study was to determine the factors that affect the profitability of broiler farmers in that region and the relation between these factors and the social-economic-cultural situation of these farmers, and also to identify the main problems faced by the farmers.

\section{MATERIAL AND METHODS}

The survey was conducted between February and March of 2011 with 91 randomly selected broiler farmers from eight different cities of Southwestern Paraná. Each farmer answered a questionnaire with 39 questions about 14 production factors, including farmer's age and education level, land possession, family size, size and number of broiler houses, type of labor, capital invested in broiler farming, annual family income, training exposure, broiler farming experience, credit needs, technical service, production problems and bird weight at slaughter, as proposed by Ali \& Hossain (2010).

Farmer's age was determined as the number of years of life. Education level was the number of years the farmer attended school. Land ownership was farm total area. Family size was the total number of family members. Labor was classified as family labor, hired labor, or a combination of family and hired labor. Gross income was the average revenue obtained per flock. Training exposure factor was determined by the number of days that the farmers attended to training courses. Broiler farming experience was determined by the number of years that the farmer has worked in this activity. Bird weight at slaughter was obtained by calculating average slaughter weight of the previous three flocks.

Credit needs (CN) for the broiler production was obtained from the equation suggested by Kashem (1986): $C N=(R C-C R) \times 100 / R C$, where $R C$ is required credit and CR is credit received. Technical service was determined by the frequency that the support services were offered, divided into four categories: frequent service, occasional service, rare service, or no service assistance, which were scored as 3, 2, 1, and 0 , respectively.

The financial performance of broiler production was determined as a function of cost-benefit ratio (CBR) of broiler production, according to the equation: CBR = Benefit/Cost, where "Benefit" is the total revenue obtained in the previous year and "Cost" is the total cost in the previous year. The financial performance determined by the 'CBR was classified in three categories as follows: high performance, intermediate performance, and low performance.

The problems related with broiler production were classified as severe, medium, light and none, and scored as 3, 2, 1 and 0, respectively. The impacts caused by these problems were determined according to the index proposed by Ali \& Hossain (2010), as follows: $\mathrm{PFI}=3 \times \mathrm{fs}+2 \times f \mathrm{fm}+1 \times f \mathrm{fl}+0 \times f n$, where PFI is the Problem Faced Index, "fs" is the number of the farmers that faced severe problems, " $\mathrm{fm}$ " is the number of the farmers that faced medium problems, " $\mathrm{fl}$ " is the number of farmers that faced light problems and " $\mathrm{fn}$ " is the number of farmers that faced no problems (none).

PFI was calculated accounting for the 15 main problems reported by broiler farmers, such as high production cost, environmental challenges, delay of feed delivery, poor feed conversion, high bird density, management problems, power outage, low quality feed, labor issues, lack of technical support, low quality chicks, inadequate use of technology, low price of chicken meat, low quality bedding material, low quality drinking water. PFI is scored between 0 and 273 , where 0 indicates absence of problems and 273 indicates occurrence of severe problems.

The results were compared using descriptive analysis and were grouped in tables to allow a better visual comparison, discussion and presentation of results (Lopes et al., 2004). Pearson's coefficient of correlation was calculated for production factors and for production financial performance. Excel was used to calculate Pearson's coefficient of correlation at 95\% confidence interval.

\section{RESULTS AND DISCUSSION}

The financial performance of broiler production determined by the cost-benefit ratio (CBR), was classified as: low (0.89 to 2.5), medium (2.6 to 4 ) and high (4.1 to 6.49), as shown in Table 1.

The results showed that $64.84 \%$ of the broiler farmers interviewed obtained low and medium performances, whereas $35.16 \%$ obtained high financial performance. These results agree with the findings of Ali \& Hossain (2010), who observed that $78 \%$ of the farmers interviewed in Bangladesh presented low to 
Mendes AS, Gudoski DC, Cargnelutti AF, Silva EJ, Carvalho EH, Morello GM
Factors that Impact the Financial Performance of Broiler Production in Southern States of Paraná, Brazil medium performance, whereas $22 \%$ of the farmers presented high performance.

Table 1 - Absolute frequency $\left(f_{i}\right)$, cumulative frequency $\left(F_{i}\right)$, absolute relative frequency $\left(\mathrm{fr}_{\mathrm{i}}\right.$ ) and accumulated relative frequency $\left(\mathrm{Fr}_{i}\right)$ of the 91 broiler farmers according to each CBR class, mean and standard deviation (Std. Deviation).

\begin{tabular}{|c|c|c|c|c|c|c|}
\hline CBR & $f_{i}$ & $\mathrm{~F}_{\mathrm{i}}$ & $\mathrm{fr}_{\mathrm{i}}(\%)$ & $\mathrm{Fr}_{\mathrm{i}}(\%)$ & Mean & $\begin{array}{c}\text { Std } \\
\text { Deviation }\end{array}$ \\
\hline $\begin{array}{l}\text { Low Performance } \\
(0,89 \text { to } 2,5)\end{array}$ & 9 & 9 & 9,89 & 9,89 & 3,71 & 0,89 \\
\hline $\begin{array}{l}\text { Medium Performance } \\
(2,6 \text { to } 4)\end{array}$ & 50 & 59 & 54,95 & 64,84 & & \\
\hline $\begin{array}{l}\text { High Performance } \\
(4,1 \text { to } 6,49)\end{array}$ & 32 & 91 & 35,16 & 100,00 & & \\
\hline
\end{tabular}

The low financial performance of broiler production in southwestern Paraná, Brazil, presented wider CBR range (0.89 to 2.5) than that calculated for Bangladesh farmers (1.03 to 1.16). The wider CBR range indicates that the financial performance of broiler farming in southwestern Paraná, Brazil, is satisfactory, since for each $R \$ 1.00$ invested, there is an average return of $\mathrm{R} \$ 1.69$ for the broiler farmers that presented low financial performance.

The low financial performance of broiler farmers in Southwestern Paraná may be related either to management procedures, health and environmental challenges, or other issues. Good management practices are essential for obtaining good broiler performance. It is important to stress that broiler production cycle is short (approximately 42 days), and therefore, any problems or mistakes are not likely to be corrected during the flock's life cycle (Leandro et al., 2006), and consequently may compromise final broiler performance.

Table 2 shows that the average age of the interviewed broiler farmers was approximately 45.25 years, and ranged between 18 and 78 years of age. Most farmers were 31 to 45 years of age. Consistent with this study, Ondersteijn et al. (2003) found that the average age of Dutch dairy farmers was approximately 39.47 years. The authors also found that $51.65 \%$ of the interviewed farmers attended school for seven years or less. This low education level may indicate that the farmers remained working in agriculture due to the lack of opportunities in the job market. Willock et al. (1999) stated that the decisions that farmers make to adjust to new circumstances are led not only by economic factors, but also by social-economic and psychological characteristics. Therefore, it is also important to further study the social factors related to broiler production (such as farmer's age and education level).
The number of family members ranged from one to seven among the interviewed farmers' families. Approximately $51.65 \%$ of the interviewed families had 3 to 5 members. The average area of the farms of the interviewed broiler farmers was approximately 16.95 hectares, with $49.45 \%$ of the farms being 5 to 19 hectares. The interviewed farmers presented an average experience with broiler production of approximately 11.4 years. Also, $72.92 \%$ of the interviewed broiler farmers possessed only one broiler house, which characterized these farms as small farms. Broiler production has been established for a long time in Southwestern Paraná, which may explain the large numbers of small farms in this region.

Table 2 shows that $78.02 \%$ of the interviewed farmers rely on the labor of family members for production activities. The predominant use of family labor in broiler production in Southwestern Paraná is mainly related to farm size, which is predominantly small in this region.

Carvalho et al. (2008), in their study on broiler production costs in Western Minas Gerais, Brazil, stated that the third main cost of broiler production activities is related to labor expenses (fixed and temporary employees), which accounts for $3.61 \%$ of total broiler production costs.

Gross income of $75.82 \%$ of the Southwestern Paraná farmers ranged between $R \$ 5,000$ and $R \$$ 8,000 , as shown in Table 2. Average bird weight at slaughter was between 1.40 and $1.50 \mathrm{~kg}$ (Table 2), because broiler production in the region is directed to the export of small chickens (1.7 kg average weight) to the Middle East.

Farmers are paid by the poultry companies that contract them. Payment amount is often complicated to determine. Schimidt (2008) studied the performance of broiler farms that sent chickens of different ages to processing plants and concluded that bird age should also be included as a factor in the calculation of farmer's payment. Kassai et al. (2003) stated that financial performance can be improved by keeping track of production costs and performance indexes. Moreover, identifying the production factors that can be improved to increase the gross income of the farmers is a substantially challenging task.

Approximately $75.53 \%$ of the interviewed farmers reported that they often attend training workshops and courses on management and production activities. It was observed that training frequency was related to the frequency that technical support was offered by the contracting companies. In general, the farmers 
Table 2 - Factors that affect the financial performance of broiler production in Southwestern Paraná.

\begin{tabular}{|c|c|c|c|c|c|c|}
\hline Production Factors & Observed & Category & $\mathrm{N}$ & $\%$ & Mean & Std. Deviation \\
\hline \multirow[t]{4}{*}{ Age (years) } & & Young (18 to 30$)$ & 8 & $8.79 \%$ & & \\
\hline & $18-78$ & Middle age (31 to 45 ) & 42 & $46.15 \%$ & 45.25 & 12.99 \\
\hline & & Older (more than 45) & 41 & $45.05 \%$ & & \\
\hline & & Total & 91 & $100.00 \%$ & & \\
\hline \multirow[t]{5}{*}{ Education Level } & & 1- Fundamental & 47 & $51.65 \%$ & & \\
\hline & $1-3$ & Education (1st to 8th grade) & 22 & $24.18 \%$ & 1.73 & 0.83 \\
\hline & & 2 - First Year of High School & 22 & $24.18 \%$ & & \\
\hline & & 3 - Second Year of High School & 91 & $100.00 \%$ & & \\
\hline & & Total & 19 & $20.88 \%$ & & \\
\hline \multirow[t]{4}{*}{ Land Possession (farm area. hectare) } & $1.5-72$ & Small farm (1 to 4$)$ & 45 & $49.45 \%$ & 16.95 & 14.32 \\
\hline & & Medium farm (5 a 19) & 27 & $29.67 \%$ & & \\
\hline & & Large farm (more than 20) & 91 & $100.00 \%$ & & \\
\hline & & Total & 40 & $43.96 \%$ & & \\
\hline \multirow[t]{4}{*}{ Family Size } & $1-7$ & Small (1 to 2 members) & 47 & $51.65 \%$ & 3.55 & 1.15 \\
\hline & & Medium (3 to 5 members) & 4 & $4.40 \%$ & & \\
\hline & & Large (more than 5 members) & 91 & $100.00 \%$ & & \\
\hline & & Total & 70 & $76.92 \%$ & & \\
\hline \multirow[t]{4}{*}{ Number of broiler houses } & $1-5$ & Small farm (1) & 20 & $21.98 \%$ & 1.29 & 0.62 \\
\hline & & Medium farm (2) & 1 & $1.10 \%$ & & \\
\hline & & Large farm (more than 3) & 91 & $100.00 \%$ & & \\
\hline & & Total & 71 & $78.02 \%$ & & \\
\hline \multirow[t]{4}{*}{ Labor Type (Score) } & $1-3$ & Strictly Familiar (1) & 11 & $12.09 \%$ & 1.32 & 0.65 \\
\hline & & Hired \& Familiar (2) & 9 & $9.89 \%$ & & \\
\hline & & Strictly Hired (3) & 91 & $100.00 \%$ & & \\
\hline & & Total & 39 & $42.86 \%$ & 1.57 & 0.5 \\
\hline \multirow[t]{3}{*}{ Capital in Broiler Farming } & $1-2$ & Partially Automated (1) & 52 & $57.14 \%$ & & \\
\hline & & Totally Automated (2) & 91 & $100.00 \%$ & & \\
\hline & & Total & 17 & $18.68 \%$ & & \\
\hline \multirow{4}{*}{$\begin{array}{l}\text { Gross Income per Flock (Brazilian real. } \\
\mathrm{R \$} \text { ) }\end{array}$} & $3,500-$ & Low (4.000 to 4.999$)$ & 69 & $75.82 \%$ & 6.161 .54 & 12.47 \\
\hline & 12,000 & Medium (5.000 to 8.000 ) & 5 & $5.49 \%$ & & \\
\hline & & High (above 8.000) & 91 & $100.00 \%$ & & \\
\hline & & Total & 1 & $1.10 \%$ & & \\
\hline \multirow{5}{*}{$\begin{array}{l}\text { Training Exposure (No. of training } \\
\text { courses) }\end{array}$} & $1-4$ & None (1) & 8 & $8.79 \%$ & 3.62 & 0.7 \\
\hline & & Rare (2) & 16 & $17.58 \%$ & & \\
\hline & & Occasional (3) & 66 & $72.53 \%$ & & \\
\hline & & Frequent (4) & 91 & $100.00 \%$ & & \\
\hline & & Total & 25 & $27.47 \%$ & & \\
\hline \multirow[t]{4}{*}{ Broiler Farming Experience (years) } & $2-32$ & Little Experience (1 to 4) & 44 & $48.35 \%$ & 11.4 & 7.87 \\
\hline & & Intermediate Experience (5 to 14 ) & 22 & $24.18 \%$ & & \\
\hline & & Large Experience (above 15) & 91 & $100.00 \%$ & & \\
\hline & & Total geral & 63 & $69.23 \%$ & & \\
\hline \multirow{4}{*}{$\begin{array}{l}\text { Credit Needs } \\
\text { (No. of credit) }\end{array}$} & $0-8$ & Little Need (above 1) & 25 & $27.47 \%$ & 1.99 & 1.8 \\
\hline & & Moderate Need (more than 2) & 3 & $3.30 \%$ & & \\
\hline & & Great Need (more than 5) & 91 & $100.00 \%$ & & \\
\hline & & Total & 4 & $4.40 \%$ & & \\
\hline \multirow{3}{*}{$\begin{array}{l}\text { Technical Service } \\
\text { (Score) }\end{array}$} & $1-2$ & Occasional (1) & 87 & $95.60 \%$ & 1.96 & 0.21 \\
\hline & & Frequent (2) & 91 & $100.00 \%$ & & \\
\hline & & Total & 71 & $78.02 \%$ & & \\
\hline \multirow[t]{4}{*}{ Problems Faced (number) } & $1-3$ & Few (1) & 19 & $20.88 \%$ & 1.23 & 0.45 \\
\hline & & Some (2) & 1 & $1.10 \%$ & & \\
\hline & & Many (3) & 91 & $100.00 \%$ & & \\
\hline & & Total & 29 & $31.87 \%$ & & \\
\hline \multirow[t]{4}{*}{ Bird Weight at Slaughter } & $1.31-1.70$ & Light (1.340 to $1.399 \mathrm{~kg})$ & 58 & $63.74 \%$ & 1.45 & 0.05 \\
\hline & & Intermediate $(1.4$ to $1.5 \mathrm{~kg})$ & 4 & $4.40 \%$ & & \\
\hline & & Heavy (more than $1.5 \mathrm{~kg}$ ) & 91 & $100.00 \%$ & & \\
\hline & & Total & & & & \\
\hline
\end{tabular}


Mendes AS, Gudoski DC, Cargnelutti AF, Silva EJ, Carvalho EH, Morello GM
Factors that Impact the Financial Performance of Broiler Production in Southern States of Paraná, Brazil

Education level presented a Pearson's coefficient of correlation of 0.37 with production performance, which may indicate that the farmers that attended school longer were able to apply what they learnt to the production activities, leading to better economic efficiency. Accordingly, Ondersteijn et al. (2003) observed that education level was one of the main factors that improved the performance of dairy production in the Netherlands. Similarly, Andreakos et al. (1997) and Wilson et al. (2001) stated that the education level has a substantial effect on the financial performance of agricultural activities.

The remaining factors studied, such as farmer's age, family size, broiler farming experience, number of barns, capital invested in broiler farming, training exposure, technical service, and credit needs were not significantly correlated with production performance. Goodwing et al. (2005) reported that credit needs did not represent an obstacle for the development of agricultural activities. This is explained by the fact that financial institutions currently provide more resources to this sector because land, betterments, and the financed good itself are used as contract guarantees.

Technical service presented a negative Pearson's coefficient of correlation (-0.08), as shown in Table 3. This result was expected because technical support services are offered by the contracting company, which was the same for all farmers. Therefore, the effects of technical service on the broiler farming performance are the same for all interviewed farmers.

Table 4 shows the Problem Faced Index (PFI) and the impact of the most common problems faced by the farmers on broiler farming production. Environmental challenges were found to be the main problem faced by the interviewed farmers. This demonstrates that the environmental control systems inside the broiler houses in Southwestern Paraná were not efficient to maintain the broilers within the zone of least thermoregulatory effort.

Table 4 shows that poor feed conversion was the second major problem faced by broiler farmers. Feed conversion ratio is a significant concern of farmers, since feed costs may account for $70 \%$ of the total production costs (Nascimento et al., 2005). For this reason, poultry companies make a considerable effort to achieve maximum efficiency in balancing diets in order to improve feed conversion ratio.

The third main problem faced by the interviewed farmers was related to management practices. As previously mentioned, the production cycle of broiler chickens is short (approximately 42 days), 
Mendes AS, Gudoski DC, Cargnelutti AF, Silva EJ, Carvalho EH, Morello GM
Factors that Impact the Financial Performance of Broiler Production in Southern States of Paraná, Brazil and therefore there is hardly any time to correct any problems or mistakes during the chicken's life cycle (Leandro et al., 2006). Therefore, management issues may compromise final broiler performance.

Table 4 - Score and classification of the problems faced by broiler farmers ( $\mathrm{SP}=$ Severe Problems; $\mathrm{MP}=$ Medium problems; LP = Light Problems).

$$
\text { Problem Severity }
$$

PFI Score

\begin{tabular}{lcccccc} 
Identified problems & SP & MP & LP & None & \\
\hline 1. Environmental challenges & 49 & 26 & 16 & 0 & 215 & 1 \\
2. Poor feed conversion ratio & 34 & 37 & 20 & 0 & 196 & 2 \\
\hline 3. Management problems & 26 & 45 & 20 & 0 & 188 & 3 \\
\hline 4. Low quality chicks & 35 & 25 & 31 & 0 & 186 & 4 \\
\hline 5. Delay in feed delivery & 12 & 51 & 18 & 10 & 156 & 5 \\
\hline 6. Power outage & 29 & 14 & 31 & 17 & 146 & 6 \\
\hline 7. High production costs & 14 & 34 & 12 & 31 & 122 & 7 \\
\hline 8. Low quality feed & 26 & 12 & 10 & 43 & 112 & 8 \\
9. Lack of technical service & 18 & 15 & 11 & 47 & 95 & 9 \\
10. Labor issues & 17 & 19 & 4 & 51 & 93 & 10 \\
\hline 11. Low price of chicken meat & 6 & 12 & 3 & 70 & 45 & 11 \\
\hline 12. High bird density & 8 & 10 & 0 & 73 & 44 & 12 \\
\hline 13. Improper use of technology & 7 & 9 & 4 & 71 & 43 & 13 \\
\hline 14. Low feed fuality & 7 & 4 & 11 & 69 & 40 & 14 \\
\hline 15. Low drinking water quality & 7 & 5 & 6 & 73 & 37 & 15 \\
\hline
\end{tabular}

Low quality chicks provided by the contracting company and delays in feed delivery were also reported as substantial problems by the farmers. Low quality chicks present high mortality rates during the first days of life and reduced growth rate. The delay in feed delivery directly affects bird performance. Broilers are fed ad libitum during the entire production cycle, differently from other animals, such as pigs, which are offered specific amounts of feed for a limited amount of time during the day. Therefore, the lack of feed available for long periods of time leads to poor broiler bird performance and financial losses.

The remaining identified problems related to broiler farming in Southwestern Paraná included the low quality of drinking water and bedding material; stocking density; labor issues; low market prices of chicken meat; power outage, which stops the operation of environmental-control systems; and high production costs, due to the high prices of wood to feed the brooders during the winter and high expenses with electricity to run the ventilation fans during the summer. Carvalho et al. (2008) reported that the high electricity costs accounted for $1.10 \%$ of total broiler production costs in Western Minas Gerais, Brazil. Moreover, contracts between the broiler companies and the farmers do not entirely protect the farmers, who are then partially liable to the risks associated with broiler production (Figueiredo et al., 2006).

Zilli et al. (2005) studied the role and importance of labor on broiler farm management in Brazil. The authors stressed the importance of the broiler production in Brazil and reported its significant progress in genetics, health, nutrition, and technology. However, according to those authors, information on the characteristics and situation of broiler farmers in Brazil are still lacking. According to Santos \& Marion (1993), the success of an agricultural company is related to its management performance, as well as to the technical and administrative abilities of efficiently using the available resources for production activities. Gathering consistent information on local agricultural activities is a challenging task, but it is essential to support decision making and to improve production performance.

\section{CONCLUSIONS}

This study showed that, in general, broiler chicken farms in Paraná, Brazil, are small and family driven. In average, farmers in this region presented medium to low financial performance. Farmers were in average 45 years old. Young people (below 25 years) are no available to work in farm activities. Environmental challenges were the main problem faced by broiler farmers, leading to increased costs to run environmental-control systems.

\section{REFERENCES}

Ali MS, Hossain MM. Factors influencing the performance of farmers in broiler production of Faridpur District in Bangladesh. World's Poultry Science Journal 2010; 66:123-131.

Andreakos I, Tzouvelekas V, Mattas K, Papanagiotou E. Estimation of technical efficiency in greek livestock farms. Cahiers d'Economie et Sociologie Rurales 1997;42:93-107.

Carvalho FM, Fiúza MA, Lopes MA. Determinação de custos como ação de competitividade: estudo de um caso na avicultura de corte. Ciências Agrotécnicas 2008; 32(3):908-913.

Duffy M, Nanhou V. Factors in the Success of Farms and the Relationship Between Financial Sucess and Perceived Sucess. Ames: Yowa State University, Staff General Research Papers; 2003.

Figueiredo AM, Santos PA, Santolin R, Reis BS. Integração na criação de frangos de corte na microrregião de Viçosa - MG: viabilidade econômica e análise de risco. Revista Engenharia Rural 2006;44(4):713-730.

Goodwin HL, Ahrendsen BL, Barton TL, Denton JH. Estimated Returns for Contract Broiler Production in Arkansas, Missouri, and Oklahoma: Historical and Future Perspectives. Journal of Applied Poultry Research 2005;14:106-115. 
Mendes AS, Gudoski DC, Cargnelutti AF Silva EJ, Carvalho EH, Morello GM
Kassai JR, Kassai S, Corrar LJ, Leite HC. Ponto de equilíbrio na atividade rural [retrieved 30 Out 2003]. São Paulo: USP; 2003. Available at: http://www.eac.fea.usp.br.

Leandro NSM, Cunha WCP, Stringhini JH, Cruz CP, Café MB, Matos MS. Influência do peso inicial de pintos de corte sobre o desempenho e o rendimento de carcaça de frangos e a viabilidade econômica da produção. Revista Brasileira de Zootecnia 2006:35(6):2314-2321.

Lopes MA, Lima ALR, Carvalho FM, Reis RP, Santos IC, Saraiva FH. Controle gerencial e estudo da rentabilidade de sistemas de produção de leite na região de Lavras (MG). Ciência e Agrotecnologia 2004;28(4):883-892.

Nascimento GAJ, Costa FGP, Junior VSA, Barros LR. Efeito da substituição do milho pela raspa de mandioca na alimentação de frangos de corte, durante as fases de engorda e final. Ciências Agrotécnicas 2005;29(1):200-207

Ondersteijn CJM, Giesen GWJ, Huirne RBM. Identification of farmer characteristics and farm strategies explaining changes in environmental management and environmental and economic performance of dairy farms. Agricultural Systems 2003;78:31-55.

Pereira Fl. Modelo de mensuração e gestão de custos no setor primário: aplicabilidade no segmento avícola [retrieved 10 Nov 2003]. Boa vista: UFR; 2003. Available at: http://www.contabeis.ufpe.br/ repositorio2/18/8-3.doc.

Santos GJ, Marion JC. Administração de custos na agropecuária. São Paulo: Atlas; 1993.

Sartor FCB, Baêta FC, Luz ML, Orlando RC. Sistemas de resfriamento evaporativo e o desempenho de frangos de corte. Scientia Agrícola 2001:58(1):17-20.

\section{Factors that Impact the Financial Performance of Broiler Production in Southern States of Paraná, Brazil}

Schmidt GS. The effect of broiler market age on performance parameters and economics. Brazilian Journal of Poultry Science 2008;10(4):223-225.

Silva HA, Moraes HSKA, Guimarães VA, Hack E, Carvalho PCF. Análise da viabilidade econômica da produção de leite a pasto e com suplementos na região dos Campos Gerais - Paraná. Ciência Rural 2008;38(2):14-19.

Silva IJO, Vieira FMC. Ambiência animal e as perdas produtivas no manejo pré-abate: o caso da avicultura de corte brasileira. Archivos de Zootecnia 2010:59:113-131.

Tsoulouhas T, Vukina T. Regulating broiler contracts: Tournaments versus fixed performance standards. American Journal of Agricultural Economics 2001;83:1062-1073.

União Brasileira de Avicultura - UBABEF. Relatório Anual 2010/2011 [retrieved 15 Jun 211]. Available at: http://www.abef.com.br/ubabef.

Viana JGA, Silveira VCP. Análise econômica da ovinocultura: estudo de caso na Metade Sul do Rio Grande do Sul, Brasil. Ciência Rural 2009;39(4):1187-1192.

Willock J, Deary IJ, Edwards-Jones G, Gibson A, Dent JB, Morgan O, Grieve $R$. The role of attitudes and objectives in farmer decision making: business and environmentally oriented behaviour in Scotland. Journal of Agricultural Economics 1999;50(2):286-303.

Wilson PW, Hadley D, Asby C. The influence of management characteristics on the technical efficiency of wheat farmers in eastern England. Agricultural Economics 2001; 24:329-338

Zilli JB. Os Fatores determinantes para a eficiência econômica dos produtores de frango de corte da região Sul do Brasil: uma análise estocástica. Teoria e Evidência Econômica 2005;13(25):29-54. 